\title{
Corona Virus Pandemic: Implication on Biodiversity Conservation
}

\author{
Oluseun A. Akinsorotan ${ }^{1 *}$, Oluwatobi E. Olaniyi ${ }^{2}$, Ayomide A. Adeyemi ${ }^{1}$ and \\ Adeola H. Olasunkanmi ${ }^{1}$ \\ 1 Department of Wildlife and Ecotourism Management, College of Agriculture, Osun State University, Osogbo, Nigeria, \\ ${ }^{2}$ Department of Ecotourism and Wildlife Management, Federal University of Technology Akure, Akure, Nigeria
}

OPEN ACCESS

Edited by:

Praveen Kumar

University of Illinois at

Urbana-Champaign, United States

Reviewed by:

Munir Ahmad Nayak Indian Institute of Technology Indore, India

Ramakrishna Tipireddy,

Pacific Northwest National

Laboratory, United States

*Correspondence:

Oluseun A. Akinsorotan oluseun.akinsorotan@uniosun.edu.ng

Specialty section: This article was submitted to Water and Built Environment,

a section of the journal

Frontiers in Water

Received: 30 November 2020 Accepted: 25 March 2021

Published: 23 April 2021

Citation:

Akinsorotan OA, Olaniyi OE

Adeyemi $A A$ and Olasunkanmi $A H$ (2021) Corona Virus Pandemic:

Implication on Biodiversity

Conservation. Front. Water 3:635529.

doi: 10.3389/frwa.2021.635529
Globally, the Covid-19 pandemic affected the environment, placing a strain on the economy and all parts of human society. The effects of Covid-19 are inevitable, as there is a reduction in human pressures on the natural ecosystem because of the lockdown of social and economic activities. Ecosystem integrity (in terms of species diversity, endemism, and threats) in African countries with global hotspots for biodiversity conservation threatened. This paper provides a snapshot of the quickly growing situation caused by the Covid-19 pandemic lockdown and predicts events during normality. At present, essential conservation work (protected area/national park staff still patrol and guard vulnerable species and landscapes) is still ongoing across the globe with the accruing positive effects of the pandemic-reduced air/water pollution, short-term disruption in wildlife trafficking and ecosystem restoration. Despite this, prevailing problems such as indiscriminate exploitation of wildlife resources, tourism revenue loss, staff absenteeism/poor performance, increased human dependence on natural resources, disruptions of field/research work, and species monitoring would persist. The Covid-19 pandemic will affect conservation program funding in most African countries. Our world is changing, and the conservation community must be ready to respond appropriately.

Keywords: Africa, biodiversity conservation, Covid-19, protected areas, human society

\section{INTRODUCTION}

The Covid-19 pandemic is affecting both the physical and social environment (Corlett et al., 2020). Pandemics are large-scale outbreaks of infectious diseases that increase morbidity and mortality over a wide geographic area and cause significant economic, social, and environmental disruption (Madhav et al., 2017). The Covid-19 case is over 108.2 million and over 2.3 million people dead globally and still counting (World Health Organization, 2021). In the past, several significant diseases and pandemic such as the Spanish flu, SARS, Hong Kong flu, Ebola recorded to cause extensive disruption of the economy and conservation of biodiversity across the world (Madhav et al., 2017). Traveling and integration on the global scale, urbanization, land-use changes, and greater biodiversity exploitation led to the recent increase in pandemics (Wu et al., 2017). The Covid-19 positive and negative consequences on biodiversity resources are predictable as the present pandemic increases according to human population growth globally. Therefore, the undue pressure posed a challenge to the protection and sustainable management of biodiversity and the environment. This paper highlighted the positive and negative effects of the Covid-19 pandemic on biodiversity conservation and the implications of temporary short-term and long-term policies by governments during the pandemic. 


\section{DISCUSSION}

\section{The Impact of Covid-19 Pandemics on Biodiversity}

The Covid-19 pandemic affected virtually all sectors and the biodiversity conservation sector at local, regional and global levels (Corlett et al., 2020). Its effects on biodiversity conservation are many and either negative or positive in form, but the negative impact outweighed the positive one (Muhumuza and Balkwill, 2013; Roe et al., 2015; Corlett et al., 2020). In the same vein as the previous disease outbreaks, Covid-19 led to the inability to manage the protected areas and carry out conservation programs because of the total lockdown (Corlett et al., 2020). The effects include.

\section{The Positive Impact of the Pandemic on Biodiversity Conservation \\ Reduced Atmospheric Pollution}

Globally, there have been problems of pollution and carbon emissions throughout the world. However, the challenge of pollution reduced with improved air quality and the environment since the inception of the Covid-19 pandemic owed to industries and transport shut down (Corlett et al., 2020; Watts and Kommenda, 2020). Besides, there will be a reduced impact on marine systems because of the decline in shipping worldwide. $\mathrm{NO}_{2}$ is one of the primary drivers of air quality degradation in industrialized and urban areas (Lelieveld et al., 2015; Atkinson et al., 2018). During the total lockdown period (JanuaryApril 2020), the $\mathrm{NO}_{2}$ contents substantially decreased on an average by 40 and $20-38 \%$ over Chinese cities and Western Europe/United States of America related to the same period in 2019 (Bauwens et al., 2020). The NASA Earth Observatory (2020) recorded $6 \%$ reductions in $\mathrm{NO}_{2}$ content globally (see Table 1 ). The problem of pollution is bound to continue after the pandemic lockdown. At present, the pandemic has done a great favor to the atmosphere and the environment at large.

\section{Reduced Human Pressure on Wildlife}

The exploitation of wildlife resources may reduce as protected areas (PAs) staff expected to continue with anti-poaching patrol invariably, vulnerable species are guarded (Corlett et al., 2020). The no-vehicular movement from Covid-19 lockdown makes movement in and out of the protected areas difficult for the poachers (who traveled a long distance to hunt in the park) and loggers, reducing the rate of disturbance in the PAs. This increase the possibility of restoring wild animals to their natural environment without being disturbed by human or poaching activities (Teletchea, 2017). The natural environment will be more enriched as a new flush of animals with vegetations will sprout out because of low anthropogenic pressure (Corlett et al., 2020). For instance, Covid-19 improved conservation in the protected areas of Nepal (Neupane, 2020). This improvement owed to reduced vehicular movement and human pressures. The temporary ban on trade and bushmeat consumption in February 2020 reduced the undue human pressure on the protected and conserved areas in China (Hockings et al., 2020). The implication of a temporary and permanent ban on wildlife trade and trafficking is unknown because of insufficient data for meaningful analysis and conclusion. Broad (2020) opined that the study of the Covid-19 pandemic on the wildlife trade routes and current measures to combat wildlife trafficking in various countries involves sufficient data collected over a long period. However, Wittig (2020) stated that aggressive global counterwildlife trafficking measures during the Covid-19 pandemic diminish the operations/supply chains of the wildlife traffickers and demand of the consumers in the long term.

\section{Negative Impact of Pandemic on Biodiversity Loss of Skilled Personnel and Funds}

Economically, pandemics imposes high financial costs on both government and conservation organization. The highly trained staff lost to a pandemic is devastating in developing countries where conservation capacity is limited. For instance, 40 Rangers experienced job losses in the Mara Nabisco Conservancy in Kenya because of the pandemic on tourism revenues used to pay their salaries (International Union for Conservation of Nature, 2020). In the same vein, Waithaka (2020) confirmed the loss of employment and livelihood among the protected area staff in most African countries because of 60-100\% tourism revenue loss. Therefore, the training cost for the newly employed will be high.

\section{Ineffective and Lukewarm Staff}

Absenteeism will be on the rise among the personnel. Psychologically, staff members will choose to care for their sick relatives than going to work. For instance, many protected areas in Nepal, Africa, Latin America and other parts of Asia experienced poor attendance by workers because of the outbreak of the Covid-19 pandemic (Conservation International, 2020; Neupane, 2020). This personnel attitude led to an increased number of poaching incidents, deforestation, bushmeat consumption and wildlife loss in Uganda and Cambodia during the lockdown period in the year 2020 (Conservation International, 2020; Greenfield and Muiruri, 2020; United Nations, 2020).

\section{Weakened Performance in the Protected Area}

Practically, there will be little or no management/supervision of patrols for the superior officers to mandate patrol are all home with their family because of the lockdown. Therefore, the rangers will not be effective in patrols around the park and making it possible for poachers neighboring the PAs to gain easy access and poach the wildlife resources. In Africa, 57\% of the countries reported the pandemic affected conducting regular field patrols in the protected areas during the lockdown period in the year 2020 (Waithaka, 2020). Contrarily, the number of Rangers' patrols increased in 14 popular European National and Nature Parks during and after the first and second local restrictions because of the provision of personal protective equipment and installing plexiglass barriers in tourism hotspots (McGinlay et al., 2020). Also, an increase in the rate of illnesses and deaths among the protected area rangers, senior officials, game guards, and other conservation bodies' personnel will weaken their performance in the protected areas (Rija et al., 2013). This situation occurs when the wildlife staff finds it difficult to execute 
TABLE 1 | Decrease of air pollution $\left(\mathrm{NO}_{2}\right)$ across the globe during the Covid-19 lockdown period.

\begin{tabular}{|c|c|c|c|c|}
\hline Locations & Period of study & Percentage decrease (\%) & Data used & References \\
\hline China & January-April, 2020 & 40 & $\begin{array}{l}\text { Tropospheric Monitoring } \\
\text { Instrument (TROPOMI) on } \\
\text { Sentinel-5, Ozone Monitoring } \\
\text { Instrument (OMI) on Aura } \\
\text { platform }\end{array}$ & Bauwens et al., 2020 \\
\hline China & $\begin{array}{l}\text { 1st January-25th February, } \\
2020\end{array}$ & 25 & NASA Satellite data & NASA Earth Observatory, 2020 \\
\hline Western Europe & January-April, 2020 & $20-38$ & TROPOMI, OMI & Bauwens et al., 2020 \\
\hline USA & January-April, 2020 & $20-38$ & TROPOMI, OMl & Bauwens et al., 2020 \\
\hline Global & January-February, 2020 & 6 & NASA Satellite data & NASA Earth Observatory, 2020 \\
\hline Paris & January-February, 2020 & 54 & NASA Satellite data & Bouillon-Minois et al., 2020 \\
\hline Po River Plain, Italy & January-February, 2020 & Decreased (not specified) & NASA Satellite data & Mannucci, 2020 \\
\hline
\end{tabular}

their duties and enforce the law when sick. Even the most committed worker will become less or unproductive because of successive bereavement that will undermine their morale and enthusiasm. Poachers will take advantage to hunt wildlife illegally while wildlife staff members are sick, looking after their sick relatives, or attending funerals.

\section{Reduced Revenue and Staff Strength}

Tourism revenue is the source of funding for protected area agencies. It provides the means for livelihood improvement of local communities and national development through foreign exchange (Anand and Kim, 2021). Loss of tourism revenues in protected areas leads to joblessness through staff dismissal (Weaver and Makiwa, 2020) and non-organized monitoring programs. Presently, there is insufficient data on the impact of the Covid-19 on tourism revenues in various countries. The fluctuation of the tourist number in the world can better explain the dynamics of tourism revenue. According to UNWTO (2020), 100\% of countries with tourism destinations introduced travel restrictions because of Covid-19, and the pandemic caused a drastic decrease in tourist numbers (290440 million) at a rate of $20-30 \%$ during 2020 globally (Figure 1).

\section{Human/Resource Conflict}

The effect of lockdown and other pandemic associated factors can cause conflicts and destruction of natural resources. For instance, conflicts will arise when the behavior of local people changes because of difficult livelihood. The inability of rural households to farm and food insecurity leads to increased poverty among the local communities. According to the World Bank (2020), the Covid-19 pandemic will acerbate the poverty of 176 million people worldwide. The high poverty rate will increase the dependence of vulnerable communities and households on natural resources (FAO, 2020). In Thailand, reversed migration to rural areas occurred among those who lost their jobs in the urban area (Thai PBS, 2020). This migration led to undue pressure on natural resources in protected areas. Also, households that have lost their breadwinners to the course of the pandemic will be alone without an option for meeting their subsistence and income needs. World Bank (2020) stated that pandemic incapacitated productive adults in the household. Therefore, they divert to other available strategies which are unsustainable and ecologically destructive such as the killing of wildlife species and destruction of habitats so as for them to cope (Kideghesho and Msuya, 2012).

\section{Increase in Local Exploitation}

The physical environment is also affected as many plants and animals exploited. During this present pandemic (Covid19), many wild animals species killed by the locals for consumption. The pandemics have also aroused the beliefs of susceptible households in countries with biodiversity-rich ecosystem resulting in land clearing, illegal logging and mining (McCauley et al., 2013; McNeely, 2021). This belief change contributed to the overexploitation of biodiversity resources for their survival. For instance, the forest clearing in the Brazilian Amazon increased by $34 \%$ during the pandemic in 2020 (Escobar, 2020). Besides, natural resources extracted for traditional medicines. On a quest to find treatments for the pandemic and related chronic diseases by traditional healers, concoctions made from parts of wild animals and some forest trees. This method of treating pandemic can cause harm to the environment. According to Somerville (2020), the illegal harvest of Rhinoceros (Diceros bicornis and Ceratotherium simum) increased in Botswana because of the high demand for its horn to treat the Covid-19 virus in traditional Chinese medicine.

\section{Lack of Research, Assessment, and Monitoring on Biodiversity}

The inability to conduct research and or identify the changes (lost and or movement of new species into an ecosystem) in the elements of biological diversity through monitoring programmes in a protected landscape speed up the rates of loss. Lockdown and social distancing because of the pandemic will inhibit rangers and other conservation scientists to provide 


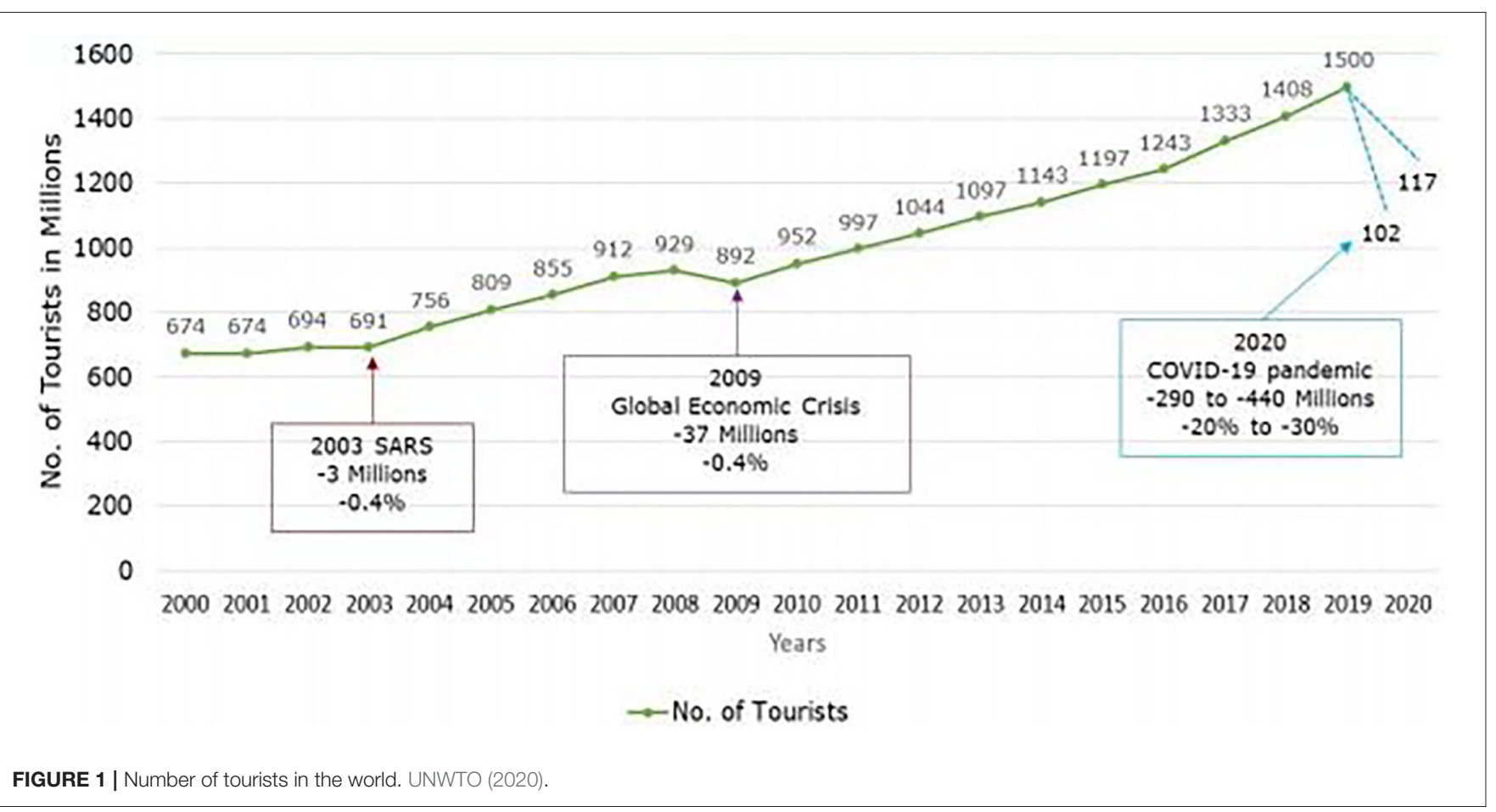

information on the trends in primary species and other aspects of PAs. Many research, internship/industrial training in wildlife/biodiversity conservation disrupted. Researchers can no longer conduct field-based social research that requires interviews or focus groups because of the possibility of disease transmission. The continuing shortage of funds can be the fundamental barrier to biodiversity assessment and more effective monitoring programmes in Africa. This fund shortage acerbates the unprecedented global recession driven by the Covid-19 pandemic. In the absence of such informative data, the missed research means missed opportunities to identify conservation priorities, monitor the health of endangered species and ecosystems, and provide practical solutions for the protection and sustainable use of resources on which human well-being depends.

\section{REFERENCES}

Anand, A., and Kim, D. H. (2021). Pandemic induced changes in economic activity around african protected areas captured through night-time light data. Remote Sens. 13:314. doi: 10.3390/rs13020314

Atkinson, R. W., Butland, B. K., Anderson, H. R., and Maynard, R. L. (2018). Long-term concentrations of nitrogen dioxide and mortality: a meta-analysis of cohort Studies. Epidemiology 29, 460-472. doi: 10.1097/EDE.0000000000000847

Bauwens, M., Compernolle, S., Stavrakou, T., Müller, J.-F., van Gent, J., Eskes, H., et al. (2020). Impact of coronavirus outbreak on $\mathrm{NO}_{2}$ pollution assessed using TROPOMI and OMI observations. Geophys. Res. Lett. 47:e2020GL087978. doi: 10.1029/2020GL087978

Bouillon-Minois, J. B., Lesage, F. X., Schmidt, J., and Dutheil, F. (2020). Coronavirus and exceptional health situations: the first disaster with benefits on air pollution Disaster Med. Public Health Prep. 14, e28-e30. doi: $10.1017 / \mathrm{dmp} .2020 .174$

\section{CONCLUSION}

Covid-19 pandemic remains a threat to biodiversity conservation through tourism revenue loss in PAs. The financial loss affects the budget, population monitoring/assessment programs, and job loss to negative human behavior that drives humanwildlife conflicts and natural resources destruction. Pollution and poaching activities may increase or decrease depending on accessibility to locals and vehicular restriction to long-distant poachers. In conclusion, there is a need to end the illegal wildlife trade globally to prevent future pandemic and biodiversity loss.

\section{AUTHOR CONTRIBUTIONS}

All authors contributed to the development of this manuscript.

Broad, S. (2020). Wildlife Trade, Covid-19 and Zoonotic Disease Risks, Traffic Briefing Paper. The Wildlife Trade Monitoring Network (TRAFFIC). Available online at: https://www.traffic.org/publications/reports/wildlife-trade-covid19-and-zoonotic-disease-risks-shaping-the-response/

Conservation International (2020). Impact of Coronavirus on Nature. Available online at: https://www.conservation.org/stories/impact-of-covid-19-onnature (accessed August 31, 2020).

Corlett, R. T., Primack, R. B., Devictor, V., Maas, B., Goswami, V. R., Bates, A. E., et al. (2020). Impacts of the coronavirus pandemic on biodiversity conservation. Biol. Conserv. 246:108571. doi: 10.1016/j.biocon.2020.108571

Escobar, H. (2020). Deforestation in the Brazilian Amazon is still rising sharply. Science 369:613. doi: 10.1126/science.369.6504.613

FAO (2020). COVID-19: Investing in Sustainable Natural Resource Management for Green and Inclusive Recovery in Asia and the Pacific. Bangkok: FAO.

Greenfield, P., and Muiruri, P. (2020). Conservation in Crisis: Ecotourism Collapse Threatens Communities and Wildlife. The Guardian. Available online at: https://www.theguardian.com/environment/2020/may/05/conservation-in- 
crisis-covid-19-coronavirus-ecotourism-collapse-threatens-communitiesand-wildlife-aoe (accessed May 5, 2020).

Hockings, M., Dudley, N., Elliot, W., Napolitano, M., MacKinnon, K., Pasha, M. K. S., et al. (2020). COVID-19 and protected and conserved areas. Parks 26, 7-24. doi: 10.2305/IUCN.CH.2020.PARKS-26-1MH.en

International Union for Conservation of Nature, IUCN. (2020). Conserving Nature in a Time of Crisis: Protected Areas and COVID-19. Available online at: https:// www.iucn.org/news/world-commission-protected-areas/202005/conservingnature-a-time-crisis-protected-areas-and-covid-19 (accessed May $25,2020)$.

Kideghesho, J. R., and Msuya, T. S. (2012). "Managing the wildlife protected areas in the face of global economic recession, HIV/AIDS pandemic, political instability and climate change: experience of Tanzania," in Protected Areas Management, ed B. Sladonja (Rijeka: InTech), 65-91. doi: 10.5772/51335

Lelieveld, J., Evans, J. S., Fnais, M., Giannadaki, D., and Pozzer, A. (2015). The contribution of outdoor air pollution sources to premature mortality on a global scale. Nature 525, 367-371. doi: 10.1038/nature15371

Madhav, N., Oppenheim, B., Gallivan, M., Mulembakani, P., Rubin, E., and Wolfe, N. (2017). "Pandemics: risks, impacts, and mitigation," in Disease Control Priorities: Improving Health and Reducing Poverty, 3rd Edn., eds D. T. Jamison, H. Gelband, S. Horton, S., P. Jha, R. Laxminarayan, C. N. Mock, and R. Nugent (Washington, DC: The International Bank for Reconstruction and Development/The World Bank), 315-345. doi: 10.1596/978-1-4648-0527-1_ch17

Mannucci, P. M. (2020). Traffic-related air pollution and the coronavirus pandemia: shadows and lights. Euro. J. Prev. Cardiol. 1-4. doi: $10.1177 / 2047487320928451$

McCauley, M., Minsky, S., and Viswanath, K. (2013). The H1N1 pandemic: media frames, stigmatization and coping. BMC Public Health 13:1116. doi: 10.1186/1471-2458-13-1116

McGinlay, J., Gkoumas, V., Holtvoeth, J., Fuertes, R. F. A., Bazhenova, E., Benzoni, A., et al. (2020). The Impact of COVID-19 on the Management of European Protected Areas and Policy Implications. Forests 11:1214; doi: 10.3390/f11111214

McNeely, J. A. (2021). Nature and COVID-19: the pandemic, the environment, and the way ahead. Ambio 50, 767-781. doi: 10.1007/s13280-020-01447-0

Muhumuza, M., and Balkwill, K. (2013). Factors affecting the success of conserving biodiversity in national parks: a review of case studies from Africa. Int. J. Biodiversity 2013:798101. doi: 10.1155/2013/798101

NASA Earth Observatory (2020). Airborne Nitrogen Dioxide Plummets over China. Available online at: https://earthobservatory.nasa.gov/images/146362/ airborne-nitrogen-dioxide-plummets-over-china (accessed August 31, 2020).

Neupane, D. (2020). How conservation will be impacted in the COVID-19 pandemic. Wildlife Biol. 2020, 1-2. doi: 10.2981/wlb. 00727

Rija, A. A., Kideghesho, J. R., Rija, A. A., Kideghesho, J. R., Mwamende, K. A., and Selemani, I. (2013). Emerging issues and challenges in conservation of biodiversity in the rangelands of Tanzania. Nat. Conserv. 6, 1-29. doi: $10.3897 /$ natureconservation.6.5407

Roe, D., Booker, F., Day, M., Zhou, W., Allebone-Webb, S., Hill, N. A., et al. (2015). Are alternative livelihood projects effective at reducing local threats to specified elements of biodiversity and/or improving or maintaining the conservation status of those elements? Environ. Evidence 4, 22. doi: 10.1186/s13750-015-0048-1

Somerville, K. (2020). COVID-19 Increases the Pressure: Botswana's RhinoPoaching Crisis. Global Geneva. Available online at: https://www.globalgeneva.com/botswanas-rhino-poaching-crisis-covid-19-increases-thepressure/ (accessed April 11, 2020)

Teletchea, F. (2017). "Wildlife conservation: is domestication a solution," in Global Exposition of Wildlife Management, ed G. A. Lameed (Rijeka: InTech), 1-21. doi: $10.5772 / 65660$

Thai PBS (2020). Conflict: Cockle Farming in Bandon Bay [video]. Available online at: https://www.youtube.com/watch?v=eLx_YVfkCd4 (accessed June 18, 2020).

United Nations (2020). Policy Brief: COVID-19 and Transforming Tourism. Available online at: https://www.un.org/sites/un2.un.org/files/sg_policy_brief_ covid-19_tourism_august_2020.pdf (accessed August 31, 2020).

UNWTO (2020). World Tourism Barometer. United Nations World Tourism Organ. 18, 1-36. doi: 10.18111/wtobarometereng.2020.18.1.5

Waithaka, J. (2020). The Impact of Covid-19 Pandemic on Africa's Protected Areas Operations and Programmes. Available online at: https://www.iucn.org/sites/ dev/files/content/documents/2020/report_on_the_impact_of_covid_19_doc_ july_10.pdf. Pp44 (accessed August 31, 2020).

Watts, J., and Kommenda, N. (2020). Coronavirus Pandemic Leading to Huge Drop in Air Pollution. The Guardian. Available online at: https://www.theguardian. com/environment/2020/mar/23/coronavirus-pandemic-leading-to-hugedrop-in-air-pollution23/03/2020

Weaver, C., and Makiwa, T. (2020). Covid-19 Threatens the Legacy of Long-Term Investment and Success in the Community-Based Conservation Programme of Namibia. Available online at: http://www.ccf-namibia.org/urgent-appeal-forsupport-for-community-game-guards (accessed August 31, 2020).

Wittig, T. (2020). How Will COVID-19 Impact Global Wildlife Trafficking? United for Wildlife. Special Analysis Series: SA-010420, 6.

World Bank (2020). Projected Poverty Impacts of COVID-19 (coronavirus) [online]. Washington, DC. Available online at: https://www.worldbank.org/en/ topic/poverty/brief/projected-povertyimpacts-of-COVID-19) (accessed June $8,2020)$.

World Health Organization (WHO) (2021). COVID-19 Situation Report, Weekly Epidemiological Report 27, 26.

Wu, T., Perrings, C., Kinzig, A., Collins, J. P., Minteer, B. A., and Daszak, P. (2017). Economic providence, Rhode Island growth, urbanization, globalization, and the risks of emerging infectious diseases in China: a review. Ambio 46, 18-29. doi: $10.1007 / \mathrm{s} 13280-016-0809-2$

Conflict of Interest: The authors declare that the research was conducted in the absence of any commercial or financial relationships that could be construed as a potential conflict of interest.

Copyright (C) 2021 Akinsorotan, Olaniyi, Adeyemi and Olasunkanmi. This is an open-access article distributed under the terms of the Creative Commons Attribution License (CC BY). The use, distribution or reproduction in other forums is permitted, provided the original author(s) and the copyright owner(s) are credited and that the original publication in this journal is cited, in accordance with accepted academic practice. No use, distribution or reproduction is permitted which does not comply with these terms. 